\title{
Pelatihan Komunikasi Daring yang Efektif bagi Anggota Asosiasi Pengusaha Patin UKM Indonesia
}

\section{(Effective Online Communication Training for the Small and Medium Size Indonesian Catfish Producers)}

\author{
Amalia E. Maulana ${ }^{*}$, Irzal Effendi ${ }^{2}$ \\ ${ }^{1}$ Creative Marketing Program, Management Department, BINUS Business School Master Program, Bina Nusantara \\ University, Jakarta Barat, Jl. Kyai H. Syahdan No.9, Palmerah, Kecamatan Palmerah, Kota Jakarta Barat, DKI Jakarta 11480. \\ 2 Departemen Budidaya Perairan, Fakultas Perikanan dan Ilmu Kelautan, Institut Pertanian Bogor, \\ Kampus IPB Darmaga, Bogor 16680. \\ *Penulis korespondensi: amalia.maulana@binus.ac.id \\ Diterima Juni 2020/Disetujui Oktober 2020
}

\begin{abstract}
ABSTRAK
Ikan Patin sedang menjadi unggulan di pasaran Indonesia dan dunia. Perusahaan produsen ikan patin berskala besar sudah mempunyai keahlian dalam mengkomunikasikan produk-produk mereka dengan baik, terlihat dengan eksistensi komunikasi daring yang efektif. Tidak demikian dengan produsen ikan patin berskala kecil dan menengah masih membutuhkan bimbingan agar dapat bersaing merebut pasar. Hanya sebagian pelaku usaha yang tergabung dalam Asosiasi Pengusaha Patin/Catfish Indonesia (APCI) yang mahir dalam membangun komunikasi daring seperti halnya pengembangan situs web dan kampanye media sosial. Karenanya, mereka perlu dibantu untuk menghadapi tantangan persaingan yang ketat khususnya untuk meningkatkan daya saing di dunia digital. Tujuan program pelatihan ini adalah untuk memberikan kesadaran, pemahaman, dan pengetahuan tentang pentingnya untuk menampilkan brand secara daring bagi perusahaan UKM di bidang perikanan, khususnya di budi daya dan pengolahan ikan patin. Metode yang digunakan dalam kegiatan ini adalah menyusun riset pendahuluan, mendesain materi pelatihan dan konsultasi, persiapan acara pelatihan, dan evaluasi kegiatan. Pelatihan ini berhasil meningkatkan pengetahuan dan kesadaran anggota perusahaan UKM mengenai komunikasi kampanye daring yang efektif dalam pemasaran ikan patin.
\end{abstract}

Kata kunci: ikan patin, komunikasi daring, komunikasi efektif, pelatihan, UKM

\begin{abstract}
Catfish is a reigning top commodity both in the Indonesian market and overseas. Large-scale catfish farming companies have managed to communicate their products well, as evidenced by their effective online communication. However, that is not the case with small and medium-sized catfish farmers. Only some members of Asosiasi Pengusaha Patin/Catfish Indonesia (APCI) have successfully established online communication methods through websites and social media campaigns. This necessitates the rest of the members to be assisted in holding themselves up against tight competition especially in the global market through online communication training. This training program aims to raise awareness, knowledge, and understanding of the importance of small and medium-sized enterprises (SMEs) dabbling in catfish farming and production to display their products online. The methods used in this activity involve formulating initial research, designing the training materials and consultations, preparing the training program, and evaluating the program. This training program is successful in raising the awareness and understanding of the members of APCI and will be useful in further stages of implementation.
\end{abstract}

Keywords: catfish, effective campaign, online communication, SME, training

\section{PENDAHULUAN}

Ikan merupakan produk unggulan yang sedang menjadi perhatian pemerintah. Kementerian Kelautan dan Perikanan RI selalu menyuarakan pentingnya produk ikan, baik untuk konsumsi di rumah tangga sebagai sumber protein, maupun sebagai produk yang dapat meningkatkan ekonomi rakyat. Ikan patin yang merupakan nama lokal popular dari nama latin pangasius merupakan salah satu jenis ikan yang penting dan prospek untuk dikembangkan hingga ke pasar ekspor (Suryaningrum 2008).

Sampai saat ini, usaha budi daya ikan patin cukup berkembang di sentra-sentra budi daya 
ikan patin yang tersebar di sepanjang Sumatera mulai dari Lampung sampai Sumatera Utara, dengan sentra pusat produksi di Provinsi Sumatera Selatan. Pulau Kalimantan sebagai sentra produksi ikan patin ke-2 di Indonesia, dengan lumbung produksi di Provinsi Kalimantan Tengah dan Kalimantan Selatan (KKP 2019). Permintaan ikan patin nasional cukup tinggi dengan jumlah produksi 476.208 pada 2019 atau meningkat sebesar 27,59\% dari tahun sebelumnya (KKP 2020), kebanyakan dalam bentuk ikan segar dan sebagian mulai diolah dalam bentuk filet. Kebijakan penutupan keran impor filet ikan patin mendorong pengusaha nasional untuk berinvestasi di bidang industri filet ikan patin (KKP 2018a). Industri ikan patin nasional mengalami kenaikan dan penurunan, beberapa bahkan hanya bisa bertahan beberapa bulan. Penyebabnya antara lain adalah stabilitas harga ikan patin di tingkat budi daya, kontinuitas bahan baku, dan biaya produksi yang tinggi gagal ditutup oleh harga jual.

Di pasar ekspor, ikan patin sedang mendapat perhatian dunia karena minat konsumen di luar negeri meningkat. Pemerintah memberikan dukungan yang tinggi untuk kegiatan ekspor ikan, baik dari kegiatan yang diselenggarakan oleh kementerian (KKP) maupun oleh nonkementerian. Perusahaan produksi ikan patin menggunakan istilah pangasius untuk memasarkan ikan patin secara global. SMART-fish Indonesia, sebagai organisasi yang dibentuk oleh UNIDO International, ikut membantu kegiatan branding ikan patin Indonesia dengan label "Indonesian Pangasius" di tahun 2018 (http:// www.smart-fish-indonesia.org). Salah satu alat komunikasi dalam kampanye ini adalah dengan membuat situs web khusus sebagai muaranya (https://www.indonesianpangasius.com). Diharapkan dari muara situs web ini, para pembeli di pasar global bisa mendapatkan informasi yang lebih lengkap tentang produk ikan patin Indonesia ini (KKP 2018b).

Asosiasi Pengusaha Patin/Catfish Indonesia (APCI) adalah asosiasi untuk industri pengolahan dan budi daya ikan patin di Indonesia. Peran dan tanggung jawabnya adalah untuk mendukung dan mendorong pengembangan industri ikan patin yang berkelanjutan dan dalam lingkungan kompetitif di Indonesia. APCI didirikan untuk mengkomunikasikan, mengkoordinasikan, dan mendistribusikan informasi di antara anggota dan pemangku kepentingan. Organisasi ini bertujuan untuk mengembangkan industri ikan patin Indonesia di bawah satu komitmen, rencana induk yang terintegrasi dan berkelanjutan.

APCI sebelumnya memiliki nama Catfish Club Indonesia (CCI), yang dibentuk pada awal 2009 di Bogor oleh para pelaku budi daya ikan patin dan sejenisnya dari Sumatera, Kalimantan, dan Jawa. Pada musyawarah kedua tahun 2013, CCI mengubah namanya menjadi Asosiasi Pengusaha Catfish Indonesia (APCI). Anggota CCI adalah individu yang memiliki usaha di bidang budi daya ikan patin dan sejenisnya. Setelah berubah nama menjadi APCI, anggotanya bertambah tidak hanya dari kalangan pembudidaya, tapi juga para industri pengolahan ikan patin. Selain menghimpun para pengusaha budidaya ikan, anggota APCI juga terdiri dari perusahaan pengolahan ikan seperti PT Expravet Nasuba (Nasuba), PT Central Proteina Prima (CP Prima), PT Adib Global Food Supplies (AdibFood), dan lain-lain. APCI dibentuk karena mempunyai satu pandangan bahwa ikan patin merupakan komoditas potensial masa depan, mengingat keterbatasan sumberdaya lahan dan air serta peningkatan kebutuhan protein pangan. Lokasi dari APCI pusat berada di Jakarta dan APCI daerah berada di provinsi dan kabupaten.

Seiring dengan kampanye branding 'Indonesian Pangasius' ke kalangan pembeli global untuk kepentingan ekspor, berarti tingkat persiapan dari para anggota APCI harus semakin diperhatikan juga. Di sisi lain, anggota APCI sangat beragam, mulai dari yang fokus pada budi daya hingga yang fokus pada proses pengolahan ikan patin. Dari sisi skala perusahaan, ada yang berskala besar hingga yang kecil dan menengah (UKM). Saat ini anggota APCI yang sudah siap untuk promosi secara daring (online) barulah perusahaan-perusahaan yang berskala besar seperti halnya CP Prima, AdibFood, dan Nasuba. Ketiga perusahaan ini termasuk perusahaan berskala besar yang sudah siap, baik dari sisi produksi maupun komunikasi daringnya. Sedangkan, perusahaan berskala UKM masih belum menunjukkan tanda-tanda kesiapan.

Komunikasi daring belum menjadi prioritas oleh perusahaan UKM untuk saat ini, karena mereka masih lebih mengutamakan produksi dengan kualitas terbaik dan mencapai syarat mutu yang diharapkan oleh pembeli. Padahal, adopsi teknologi digital terbukti dapat meningkatkan kinerja UKM, terutama pada peningkatan akses ke pelanggan baru dan peningkatan penjualan (Slamet et al. 2016), serta meningkatkan kepuasan dan kesetiaan konsumen (Adam et al. 2020). Gambar 1 menunjuk- 
kan branding 'Indonesian Pangasius' dan APCI dan Gambar 2 menunjukkan tampilan laman situs web 'Indonesian Pangasius'.

Mengingat peran teknologi digital bagi UKM, penting untuk meningkatkan kesadaran, dan pengetahuan pelaku usaha. Selain itu, memahami pemasaran secara digital membuat perusahaan UKM dapat menanggapi adanya perubahan perilaku konsumen (Hakim 2019). Perusahaan UKM ikan patin perlu untuk diberikan pemahaman adopsi teknologi untuk memasarkan produk mereka, sehingga dapat bersaing dengan perusahaan skala yang lebih besar dan mampu menjangkau konsumen yang lebih luas.

Pelatihan yang telah dikerjakan dalam pengabdian masyarakat ini merupakan sebuah kegiatan penopang kegiatan pemerintah dalam branding Indonesian Pangasius. Tujuannya adalah agar perusahaan UKM memperoleh permintaan untuk penjualan ikan patin secara daring dan kesempatan bertransaksi dengan pembeli ekspor untuk produk ikan patin ini. Diharapkan ekspor tidak hanya jatuh ke tangan perusahaan berskala besar saja, tetapi juga bisa dinikmati oleh perusahaan kecil dan menengah. Oleh karenanya, pelatihan untuk pengelolaan brand dan komunikasi secara daring sangatlah diperlukan untuk ikut tampil dalam pasar global.

Dengan Pelatihan komunikasi daring yang efektif terhadap anggota APCI berskala UKM maka dampak dari kegiatan kampanye integrasi Indonesian Pangasius akan lebih bisa dirasakan lagi. Kesuksesan dalam bidang pemasaran ikan patin bisa lebih merata kepada semua anggota APCI. Tujuan program pelatihan ini adalah meningkatkan kesadaran, pemahaman dan pengetahuan tentang pentingnya untuk menampilkan brand secara daring perusahaan UKM budidaya dan pengolahan ikan patin, yang tergabung dalam Asosiasi APCI). Dalam jangka panjangnya, aktivitas pengusaha di dunia daring ini akan memberikan manfaat bagi perusahaan UKM ikan patin untuk ikut bermain di pemasaran ekspor ikan patin Indonesia yang sedang digalakkan oleh pemerintah dan industri.

\section{METODE PELAKSANAAN KEGIATAN}

\section{Lokasi dan Partisipan Kegiatan}

Kegiatan pengabdian kepada masyarakat dilakukan sejak Februari-September 2019.
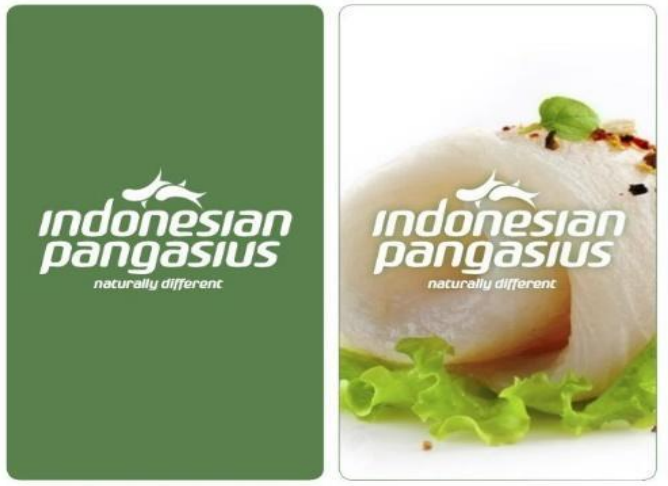

a

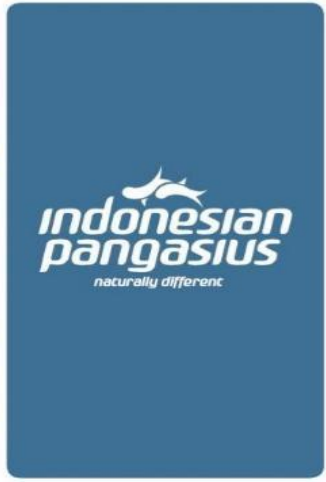

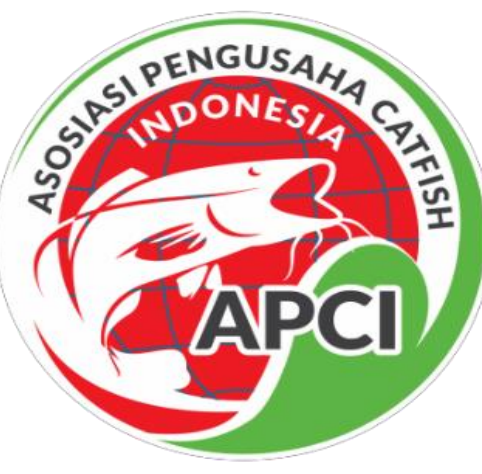

$\mathrm{b}$

Gambar 1 Branding 'Indonesian Pangasius' (a) dan asosiasi pengusaha catfish indonesia (b).
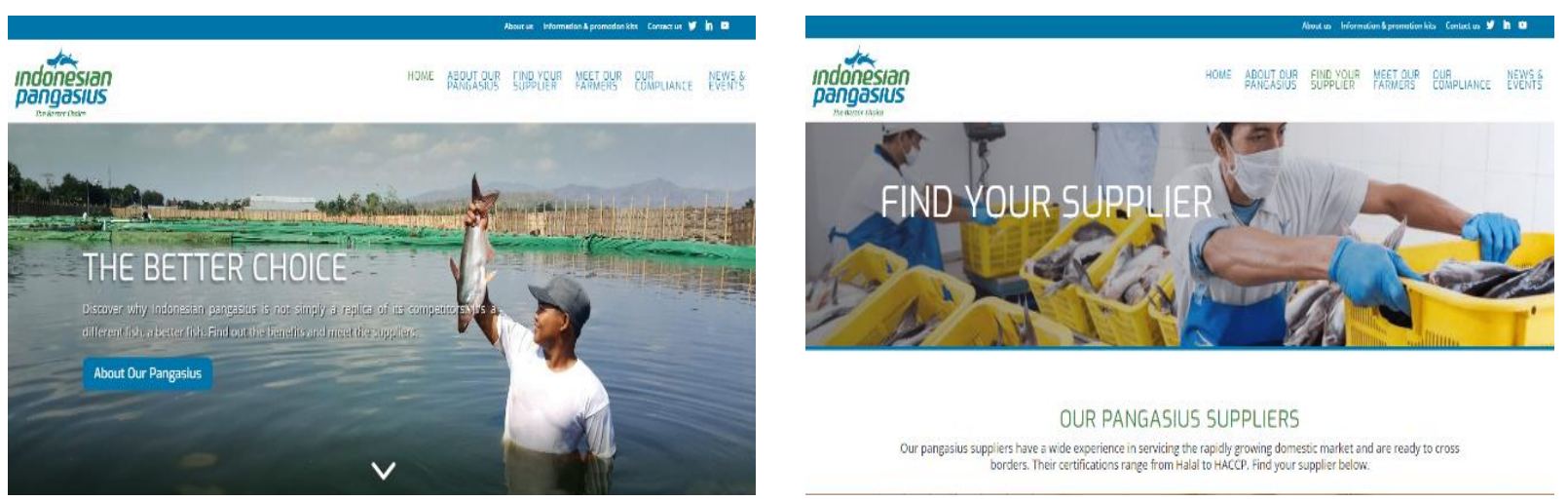

Gambar 2 a dan b Tampilan laman situs web Indonesian Pangasius. 
Peserta kegiatan ini adalah anggota UKM ikan patin yang tergabung dalam APCI. Peserta berasal dari sekitar wilayah Bogor, Jakarta, dan Purwakarta, di mana total berjumlah 27 orang. Pelatihan dilaksanakan pada 25 September 2019 di Hotel Whiz Padjajaran, Kota Bogor. Sedangkan, lokasi kegiatan untuk penelitian pendahuluan dilakukan di 3 pasar tradisional, 3 supermarket, dan 1 pasar modern yang tersebar di wilayah Kota Jakarta dan Kota Tangerang Selatan.

\section{Tahapan Pelaksanaan Kegiatan}

Tahapan yang dilakukan dalam kegiatan ini terlihat pada Gambar 3. Kegiatan ini diawali dengan pertemuan awal dengan pengurus dan anggota APCI untuk menyampaikan maksud dan tujuan kegiatan dan mendapatkan persetujuan. Setelah memperoleh persetujuan kerja sama dilakukan penelitian pendahuluan untuk memperoleh pendalaman pengetahuan tentang permasalahan yang dihadapi oleh APCI dalam penyusunan materi pelatihan. Pengumpulan data dilakukan melalui observasi dan wawancara dengan konsumen terhadap tanggapan mengenai ikan patin. Setelah data terkumpul, hasil penelitian disusun sehingga relevan dengan kebutuhan penyusunan materi pelatihan.

Dari hasil penelitian, selanjutnya dilakukan kegiatan mendesain materi pelatihan dan konsultasi yang berangkat dari permasalahan komunikasi ikan patin. Materi pelatihan disusun dan dikonsultasikan bersama dengan pengurus APCI. Setelah itu, acara pelatihan disiapkan, yaitu meliputi penentuan tempat, penyebaran undangan kepada peserta dan pengurus untuk ikut terlibat dalam pelatihan.

Pemberian materi diberikan secara presentasi dan diskusi dengan seluruh peserta pelatihan yang berlangsung selama satu hari. Peserta diminta untuk mengisi lembar jawaban berupa pre-test sebelum pelatihan dimulai dan post-test setelah mengikuti kegiatan pelatihan dengan diberikan pertanyaan sama. Bentuk pertanyaan berbentuk 10 pilihan ganda yang dapat dikerjakan melalui formulir secara daring, yaitu Google Form. Setelah kegiatan, diselenggarakan evaluasi kegiatan untuk kepentingan perencanaan, peningkatan pengetahuan peserta hingga anggaran.

\section{Riset Pendahuluan}

Pelaksanaan kegiatan pelatihan diawali dengan riset pendahuluan untuk penguasaan permasalahan lapangan ikan patin. Tahapan ini penting untuk dikerjakan sebelum menyelenggarakan pelatihan tentang bagaimana membangun branding daring ikan patin yang baik, telah dilakukan pemahaman tentang konsumen terlebih dahulu, khususnya untuk pasar domestik ikan patin.

Pengumpulan data perilaku konsumen ikan patin diperoleh melalui netnografi, yaitu metode penelitian kualitatif yang mengadaptasi teknik etnografi untuk mempelajari budaya dan komunitas yang terjadi dalam komunikasi termediasi komputer (computer mediated communications) (Kozinets 2002). Tahapan awal melalui pengumpulan data melalui media internet, seperti forum, situs web, dan platform media sosial, dan dianggap penting sebagai pengetahuan awal (Kozinets 2002). Beberapa tahap netnografi yang dilakukan melalui forum daring, situs web termasuk situs perdagangan elektronik (e-commerce), dan platform media sosial, yang bertujuan untuk memberikan gambaran mendalam terkait persepsi konsumen tentang filet ikan patin. Selain itu, netnografi juga dilakukan untuk mengetahui berbagai penamaan filet ikan patin yang tersedia di saluran distribusi daring yang juga memberi pengaruh kepada konsumen. Dalam berperilaku, setiap konsumen tidak pernah sama termasuk dalam konsumsi ikan di rumah; dan hal ini yang juga akan mempengaruhi persepsinya pada penamaan jenis ikan. Berbagai sumber di media elektronik dijelaskan pada Tabel 1.

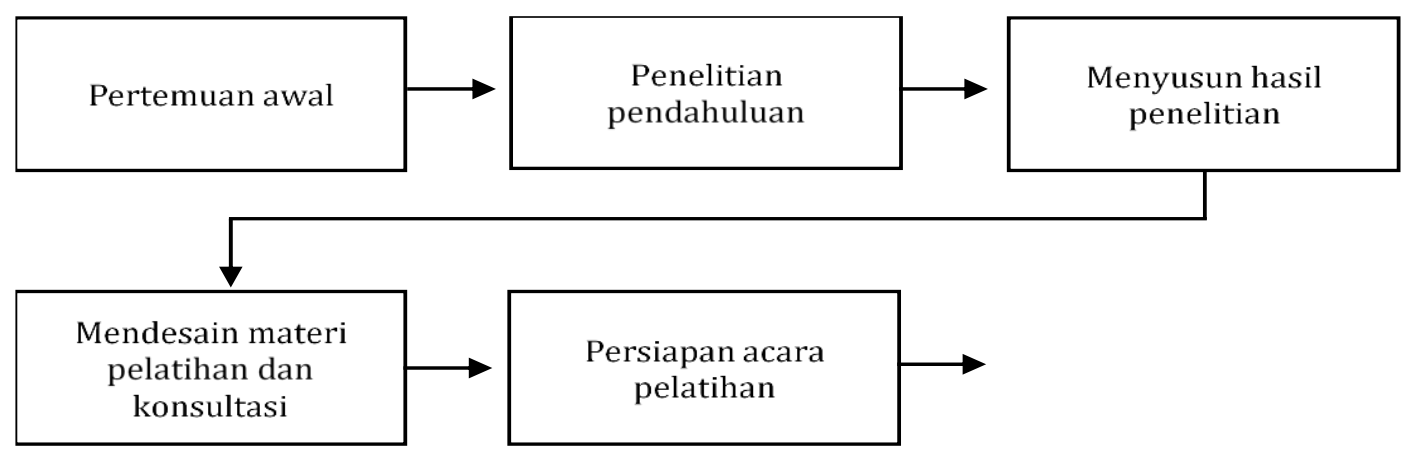

Gambar 3 Tahapan pelaksanaan kegiatan. 
Tabel 1 Sumber netnografi daring

\begin{tabular}{llll}
\hline \multicolumn{1}{c}{ Daftar forum daring } & \multicolumn{1}{c}{ Daftar berita daring } & \multicolumn{1}{c}{ Daftar situs web } & Daftar media sosial \\
\hline Kaskus.co.id & Detik.com & Shopee.co.id & Twitter \\
Fishyforum.com & Klikdokter.com & Tokopedia.com & Youtube \\
Femaledaily.com & Kumparan.com & Bukalapak.com & Facebook \\
& Tempo.co & Zomato.com & \\
& & Pergikuliner.com & \\
& & Tripadvisor.com & \\
& & Cookpad.com & \\
& & &
\end{tabular}

Selanjutnya, dilakukan penggalian pengetahuan tentang hambatan-hambatan pemasaran dengan pendekatan etnografi untuk memperoleh persepsi dan tanggapan konsumen dan pedagang terhadap ikan patin melalui observasi, wawancara terstruktur dan tidak terstruktur. Lokasi riset mencakup pasar tradisional, supermarket, dan restoran yang berada di daerah Kota Jakarta dan Kota Tangerang Selatan. Wawancara tidak terstruktur dilakukan kepada 13 orang pedagang pasar, 4 pelayan toko dan 18 orang ibu rumah tangga mewakili konsumen. Wawancara mendalam dan terstruktur dilakukan terhadap $3 \mathrm{ibu}$ rumah tangga dan 1 asisten rumah tangga. Gambaran riset pemasaran terlihat di Gambar 4.

Pengumpulan data untuk memperoleh gambaran pengetahuan peserta pelatihan dilakukan dengan penyebaran angket pre-test dan post-test. Metode pre-test dan post-test banyak digunakan dalam penelitian perilaku, terutama untuk tujuan membandingkan kelompok dan / atau mengukur perubahan yang dihasilkan secara desain eksperimental (Marsden \& Torgerson 2012). Peserta diberikan 10 pertanyaan yang relevan dengan desain materi pelatihan. Peserta mengerjakan test melalui Google Form yang disebarkan kepada peserta sekaligus untuk melatih kesiapan pemahaman daring peserta. Peserta yang hadir sebanyak 27 peserta yang terdiri dari para pengusaha dan pembudidaya ikan patin anggota APCI. Pengolahan data menggunakan aplikasi Microsoft Excel untuk mengetahui nilai rata-rata peserta pelatihan. Setelah itu, nilai rata-rata peserta sebelum dan sesudah pelatihan dibandingkan untuk melihat signifikansi peningkatan pengetahuan.

\section{HASIL DAN PEMBAHASAN}

\section{Permasalahan Ikan Patin: Penamaan Produk}

Persoalan utama dalam pemasaran ikan patin di pasar dalam negeri adalah karena masih simpang siurnya penamaannya. Hasil riset etnografi menjelaskan bahwa konsumen Indonesia masih bingung dengan penamaan ikan patin khususnya filet ikan patin. Permasalahan ini belum menjadi perhatian perusahaan UKM ikan patin. Konsumen kebingungan terhadap istilah ikan patin, ikan dori, dan ikan pangasius yang dianggap sebagai jenis ikan yang berbedabeda padahal ini merujuk kepada ikan yang sama. Studi sebelumnya juga menunjukkan bahwa kebingungan yang dirasakan oleh konsumen memiliki dampak yang negatif terhadap kepuasan konsumen (Walsh \& Mitchell 2010; Drummond \& Rule 2005). Tidak ingin mengkonsumsi lagi atau tidak membeli lagi juga merupakan tindakan yang bisa dilakukan oleh konsumen jika dihadapkan dengan kebingungan terhadap suatu produk (Mitchell \& Papavassiliou 1999). Dengan demikian, perlu kerja sama dari seluruh pihak yang berkepentingan, khususnya dari pihak asosiasi dan dukungan pemerintah. Untuk itu, peserta pelatihan disadarkan terlebih dahulu mengenai permasalahan ikan patin di Indonesia untuk memahami pemasaran ikan patin.

Sebelum melakukan sebuah kegiatan promosi, pelaku usaha harus mengetahui terlebih dahulu isu yang terkait agar kampanye pemasaran dapat disesuaikan. Jika isu yang ditangkap tidak sesuai, maka nantinya tidak tepat sasaran. Permasalahan ikan patin adalah karena brand belum dikenal dan memiliki nilai dibanding label ikan lain. Hal ini mengindikasi bahwa popularitas bukan hal utama melainkan memilih brand yang tepat. Dimulai dari problem yaitu penamaan ikan dengan kata "patin", harus diselesaikan terlebih dahulu permasalahan kategori ini. Gambar 5 menunjukkan berbagai penamaan produk ikan patin yang membingungkan konsumen.

\section{Pelatihan Komunikasi Daring yang Efektif}

Materi dalam pelatihan ini disusun berdasarkan hasil penelitian pendahuluan ikan patin. Materi utama yang disampaikan adalah 1) Komunikasi daring (online) vs luring (offline); 2) 


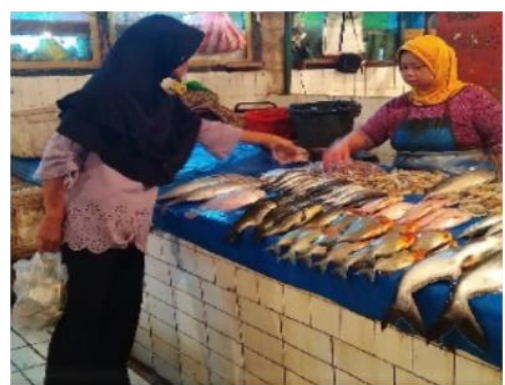

a

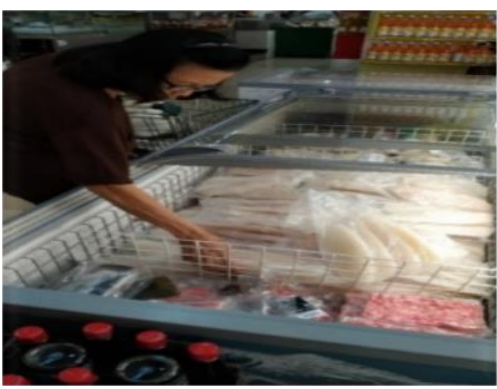

b

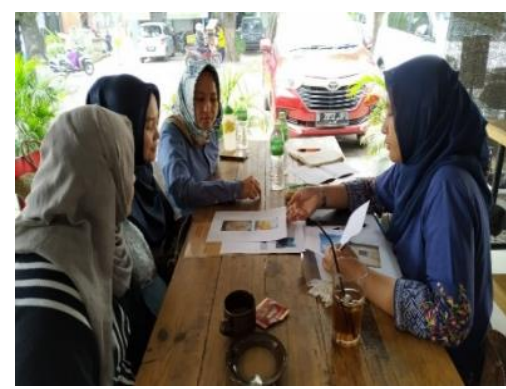

C

Gambar 4 a,b, dan c Pemahaman lapangan tentang perilaku konsumen ikan patin.

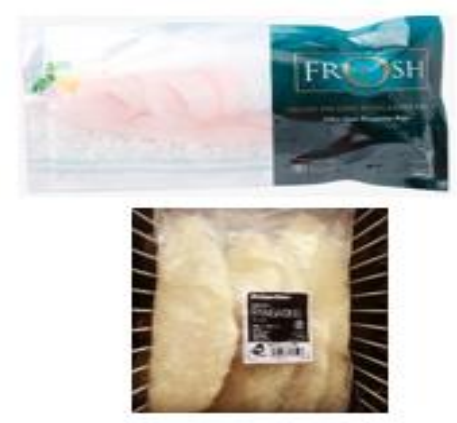

a

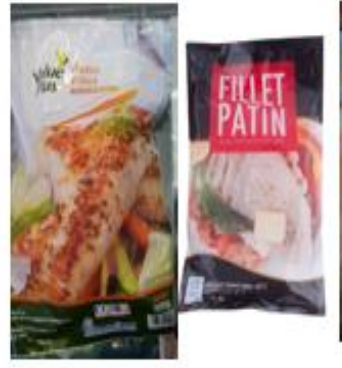

$\mathrm{b}$
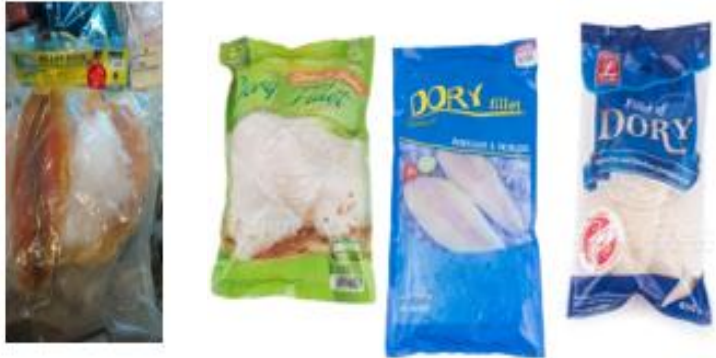

C

Gambar 5 Berbagai penamaan produk ikan patin yang membingungkan konsumen, a) pangasius, b) patin, dan c) dory.

Consumer Insights (memahami konsumen): Untuk mendapatkan informasi tentang permasalahan konsumen; 3) The power of story: mencari cerita-cerita konsumen yang positif untuk disebarkan secara daring; 4) Studi kasus untuk memberikan perspektif; dan 5) Pentingnya komunikasi yang sesuai dengan jamannya atau masa kini: tuntutan untuk menanggapi konsumen yang harus cepat melalui saluran situs web dan media sosial.

Pada materi pertama, peserta disadarkan tentang mengenai pentingnya memasukkan saluran komunikasi daring disamping komunikasi luring untuk menjangkau konsumen. Selain itu, peserta diperkenalkan mengenai berbagai saluran media komunikasi yang saat ini sudah hibrida, yaitu menggunakan media daring dan luring secara bersamaan, seperti pasar (marketplace) dalam perdagangan elektronik. Untuk itu, pedagang ikan patin pun harus dapat beradaptasi dengan menggunakan seluruh saluran media yang tersedia agar komunikasi dengan konsumen dapat berjalan.

Setelah mengetahui peran penting dari saluran daring-luring, peserta harus dapat memahami konsumen dengan melakukan riset kecil secara mandiri. Hal ini dapat dilakukan dengan membuka informasi dan mengikuti tren yang tersedia secara online. Dengan melakukan ini, perusahaan UKM ikan patin dapat memperoleh wawasan sehingga dapat selalu memperbaiki mutu dan kualitas ikan patin sesuai dengan selera pasar. Wawasan konsumen dapat dijadikan konten untuk komunikasi di berbagai saluran media yang dimiliki.

The power of story sangat dibutuhkan dalam memasarkan produk ikan patin. Media daring merupakan salah satu saluran yang perlu dikendalikan oleh pemilik produk. Selain itu, cerita dan isu negatif yang beredar di dunia daring sebaiknya direduksi karena sangat berbahaya dalam membentuk persepsi terhadap produk. Hal ini disebabkan karena semua orang dapat mengakses konten negatif di internet. Untuk itu, ikan patin harus dibuatkan cerita menarik sehingga memperoleh perhatian berbagai pihak. Cerita-cerita menarik seputar filet ikan patin bisa menjadi magnet bagi konsumen agar mulai memasukkan ikan ini dalam menunya. 'The Power of Story' menjadi pokok bahasan yang menarik dalam pelatihan ini. Secara bersamasama, APCI perlu menggali lagi berbagai "cerita patin" untuk komunikasi daringnya.

Awalnya konsumen merasa kerepotan dalam konsumsi ikan sehingga malas untuk mengkonsumsi ikan. Akan tetapi ikan patin menjadi solusi karena tersedia filet ikan patin yang lebih murah dan dapat langsung dimasak. Kalau cara 
tersebut masih tidak berhasil untuk meningkatkan konsumsi ikan, berarti pemasaran ikan patin yang harus dibenahi agar hambatan konsumsi ikan menjadi lebih rendah. Hal ini dapat dilakukan dengan strategi Integrated Marketing Engagement Communication (IMEC), di mana komunikasi daring merupakan salah satu saluran komunikasi, sehingga jika dalam integrasinya bermasalah maka bisa mengganggu proses pemasaran ikan patin.

Selama ini, perusahaan cenderung menerapkan komunikasi secara satu arah dari perusahaan ke konsumen. Sementara komunikasi pemasaran modern memiliki pola komunikasi dua arah, yaitu konsumen juga ingin bertanya. Saat ini, perilaku konsumen menuntut untuk percakapan yang serba cepat dengan perusahaan. Berbagai media komunikasi secara daring memudahkan perusahaan menjangkau para konsumen. Akan tetapi, media yang sudah tersedia, seperti situs web dan media sosial, kurang dimanfaatkan dengan baik. Hal ini disebabkan pemanfaatan media tersebut kurang maksimal dan progresif bagi konsumen. Perusahaan terkesan abai dan hanya menjawab pertanyaan konsumen melalui daring "jika sempat, baru dibalas". Selain itu, seringkali perusahaan masih menerapkan cara lama pada media komunikasi terkini sebagai alam yang baru. Padahal, membalas pesan merupakan hal yang penting meskipun berbentuk sederhana sehingga harus segera membalas pesan konsumen.

Dalam membentuk cerita yang baik terdapat beberapa hal yang perlu diperhatikan. Hal yang perlu diperhatikan terkait dengan 'memakai sepatu konsumen' yaitu perusahaan ikan patin harus membayangkan sebagai konsumen mengenai apa yang dirasakan oleh konsumen. Selain itu, perlu mempertimbangkan berbagai media yang ada melalui media digital dan non digital, di

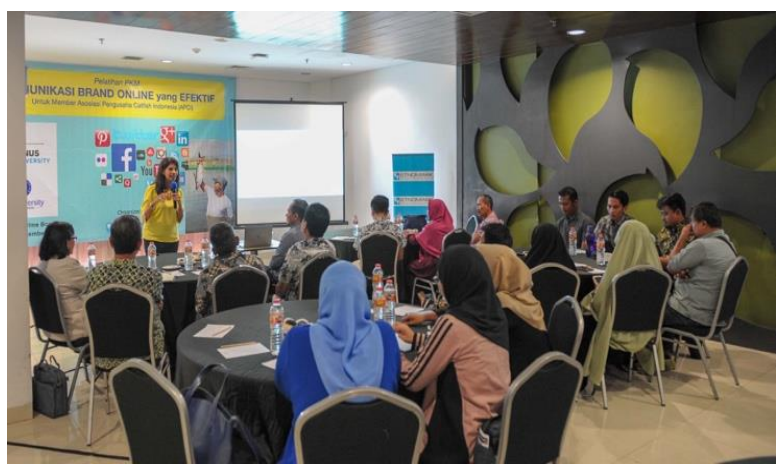

a mana perjalanan konsumen merupakan gabungan dari keduanya. Waktu penyampaian cerita yang dikampanyekan perlu memerhatikan waktu karena cerita yang terbentuk dikhawatirkan tidak akan tersampaikan. Cerita mengenai ikan patin harus mudah dicari dan membentuk consumer wisdom, yaitu terbentuk kalimat yang dapat konsumen simpulkan sendiri.

Gambar 6 menjelaskan situasi pada saat pelatihan. Acara dihadiri oleh para pengurus Asosiasi APCI, Bapak Imza Hermawan sebagai ketua dan Ibu Enny Cecilia Indriyati sebagai Sekjen APCI. Para pengurus menekankan pentingnya acara dan himbauan agar hasil pelatihan ini bisa memberikan pegangan untuk kegiatan pemasaran mereka di kemudian hari.

Kendala yang dihadapi selama pelaksanaan kegiatan adalah untuk menjaring perusahaanperusahaan di sektor ikan patin yang berada di luar Jabodetabek. Keterbatasan dana untuk pelatihan menjadi salah satu alasan bahwa mayoritas yang hadir adalah dari perusahaan yang berlokasi di Jabodetabek, ditambah dengan beberapa dari Purwakarta, Jawa Barat. Untuk kedepannya, dengan adanya teknologi seminar lewat daring, ini bisa dijadikan solusi untuk menjangkau perusahaan yan berada cukup jauh lokasinya, khususnya di luar jabodetabek.

Upaya berkelanjutan dalam kegiatan ini adalah dengan terus membangun relasi dengan para pemangku kepentingan di industri ikan patin yang berada di dalam Asosiasi APCI. Asosiasi ini menjadi penggerak dan pendorong dalam mempromosikan UKM untuk menggunakan pemasaran digital. Selain itu, Perusahaan berskala besar dalam APCI dapat berperan dalam pelatihan untuk perusahaan UKM dalam APCI sendiri, dengan menyampaikan pengalaman-pengalamannya berinteraksi dengan perusahaan global melalui komunikasi

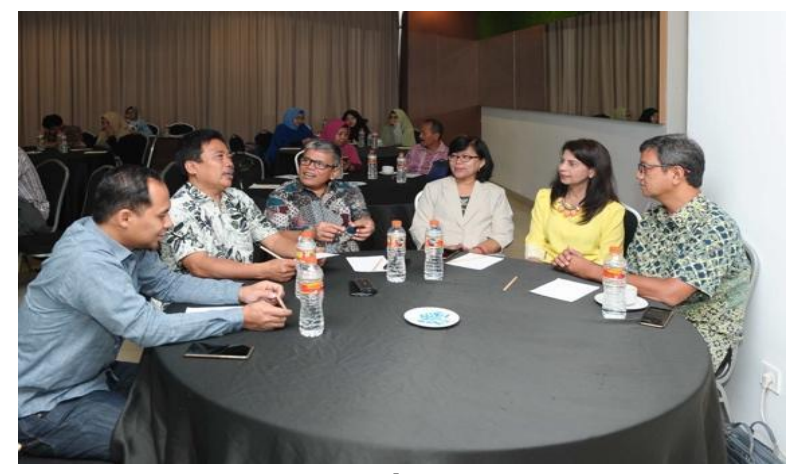

b

Gambar 6 a dan b Kegiatan pelatihan dihadiri oleh para pengurus dan anggota asosiasi pengusaha catfish indonesia. 
daring. Ini akan memberikan wawasan yang sangat baik, melanjutkan pelatihan pada program pemberdayaan masyarakat kali ini.

\section{Hasil Pre-test dan Post-test}

Tujuan dari adanya pre-test dan post-test ini adalah untuk mengukur pemahaman peserta yang mengikuti kegiatan pelatihan komunikasi daring yang efektif. Penyusunan pertanyaan yang diajukan disusun berdasarkan desain materi seputar branding daring ikan patin dalam pelatihan tersebut. Pre-test dan post-test memiliki pertanyaan-pertanyaan mengenai materi pelatihan yang diberikan kepada peserta. Keduanya memiliki struktur pertanyaan yang sama sehingga pengetahuan peserta dapat dinilai untuk melihat perbedaan dan peningkatan sebelum dan sesudah diberikan pelatihan mengenai kampanye daring.

Berdasarkan hasil pengolahan terhadap tes yang dilakukan peserta, terjadi peningkatan pengetahuan setelah diberikan pelatihan. Ratarata peserta yang menjawab dengan tepat sebelum diberikan pelatihan adalah 5,67. Sedangkan, setelah pelatihan rata-rata jawaban yang diisi dengan tepat oleh peserta naik menjadi 7,46 . Oleh karena itu, dapat disimpulkan bahwa telah terjadi peningkatan pengetahuan peserta terkait komunikasi daring yang efektif sebesar $32 \%$.

\section{SIMPULAN}

Kegiatan pengabdian masyarakat ini merupakan paduan dari ilmu pemasaran dan perikanan untuk meningkatkan kesadaran dan pengetahuan bagi UKM yang tergabung dalam APCI. Selain itu, kegiatan ini juga didahului dengan penelitian pendahuluan terhadap perilaku konsumen ikan agar mudah memahami target pasar UKM. Hasil penelitian pendahuluan menunjukkan adanya kebingungan di antara konsumen mengenai penamaan ikan patin di pasaran. Untuk itu, perlu adanya kerja sama antara asosiasi dan perusahaan ikan patin untuk menyusun strategi pemasaran dengan baik. Hasil dari penelitian ini disusun dan dikonsultasikan dengan pemangku kepentingan yang terkait dalam penyusunan materi pelatihan untuk UKM.

Kegiatan pelatihan komunikasi daring yang efektif yang dilakukan diikuti secara antusias oleh peserta dengan aktifnya peserta selama kegiatan. Selain itu, pelatihan ini berhasil meningkatkan pengetahuan peserta terhadap branding ikan patin. Langkah selanjutnya, peserta mengharapkan adanya implementasi dalam membangun branding ikan patin untuk kelompok UKM. Pelatihan ini telah menjadi sebuah awalan dari sebuah rangkaian pelatihan yang akan dilanjutkan oleh pengurus APCI karena disadari bahwa sebuah pelatihan harus melalui sebuah proses yang berlanjut dan terusmenerus. Disarankan untuk membuat sebuah penelitian percobaan salah satu perusahaan untuk membangun branding daringnya, di mana setelah itu keberhasilannya bisa dilihat secara langsung oleh perusahaan UKM lain sebagai contoh nyata.

\section{UCAPAN TERIMA KASIH}

Kegiatan pengabdian kepada masyarakat ini didanai oleh Kementerian Riset, Teknologi, dan Perguruan Tinggi Republik Indonesia, dalam skema Hibah Program Kemitraan Masyarakat melalui Universitas Bina Nusantara dengan judul "Pelatihan Komunikasi Online Yang Efektif Bagi Anggota Asosiasi Pengusaha Catfish Indonesia (APCI) Berskala Kecil dan Menengah" dengan nomor kontrak 023A/VR.SACD/V/2019 pada tanggal 29 Mei 2019.

\section{DAFTAR PUSTAKA}

Adam M, Ibrahim M, Ikramuddin I, Syahputra H. 2020. The Role of Digital Marketing Platforms on Supply Chain Management for Customer Satisfaction and Loyalty in Small and Medium Enterprises (SMEs) at Indonesia. International Journal of Supply Chain Management. 9(3): 1210-1220.

Asosiasi Pengusaha Catfish Indonesia. Tentang Kami. [Internet]. [diakses pada: 27 Februari 2020]. Tersedia pada: https://www. indonesianpangasius.com/about-us/

Drummond G, Rule G. 2005. Consumer confusion in the UK wine industry. Journal of Wine Research. 16(1): 55-64. https://doi.org/ 10.1080/09571260500236633

Hakim L. 2019. Pelatihan Pemasaran Online Berbasis Marketplace Bagi UKM Dalam Merespon Perubahan Perilaku Konsumen. 
Loyalitas, Jurnal Pengabdian Kepada Masyarakat. 2(1): 74-91.

[KKP] Kementerian Kelautan dan Perikanan RI. 2018a. Industri Patin Indonesia Rebut Pasar Global. [Internet]. [Diakses tanggal: 3 Maret 2020]. Tersedia pada: https://kkp.go.id/artikel/3163-industripatin-indonesia-rebut-pasar-global

[KKP] Kementerian Kelautan dan Perikanan RI. 2018b. Ikan Patin Asli Indonesia Resmi Gunakan Branding "Indonesia Pangasius". [Internet]. [Diakses tanggal: 3 Maret 2020]. Tersedia pada: https://kkp.go.id/djpdspkp/artikel/7571ikan-patin-asli-indonesia-resmi-gunakanbranding-indonesia-pangasius

[KKP] Kementerian Kelautan dan Perikanan RI. 2019. Laporan Kinerja Direktur Jenderal Perikanan Budidaya 2018. Jakarta (ID): Kementerian Kelautan dan Perikanan.

[KKP] Kementerian Kelautan dan Perikanan RI. 2020. Laporan Kinerja Kementerian Kelautan dan Perikanan Tahun 2019. Jakarta (ID): Kementerian Kelautan dan Perikanan.

Kozinets RV. 2002. The field behind the screen: Using netnography for marketing research in online communities, Journal of marketing research. 39(1): 61-72. https://doi.org/ 10.1509/jmkr.39.1.61.18935
Marsden E, Torgerson CJ. 2012. Single group, preand post-test research designs: Some methodological concerns. Oxford Review of Education. 38(5): 583-616. https://doi.org/ 10.1080/03054985.2012.731208

Mitchell V, Papavassiliou V. 1999. Marketing causes and implications of consumer confusion. Journal of Product \& Brand Management. 8(4): 319-342. https://doi.org/ 10.1108/10610429910284300

Slamet R, Nainggolan B, Roessobiyatno, Ramdani H, Hendriyanto A, Ilma LL. 2016. Strategi Pengembangan UKM Digital Menghadapi Era Pasar Bebas. Jurnal Manajemen Indonesia, 16(2): 136-147. https://doi.org/10. 25124/jmi.v16i2.319

Suryaningrum TD. 2008. Ikan Patin: Peluang Ekspor, Penanganan Pascapanen, dan Diversifikasi Produk Olahan. Squalen Bulletin of Marine and Fisheries Postharvest and Biotechnology. 3(1): 16-23. https://doi.org/ 10.15578/squalen.v3i1.166

Walsh G, Mitchell V. 2010. The effect of consumer confusion proneness on word of mouth, trust, and customer satisfaction. European Journal of Marketing. 44(6): 838-859. https://doi.org/ 10.1108/03090561011032739 